\title{
onmbalina
}

(8)

\section{New directions in the study of maturation and physical activity}

Autor(es): $\quad$ Cumming, Sean P.

Publicado por: Imprensa da Universidade de Coimbra

URL

persistente:

URI:http://hdl.handle.net/10316.2/38552

DOI:

DOI:http://dx.doi.org/10.14195/978-989-26-0773-3_10

Accessed : $\quad$ 26-Apr-2023 16:29:41

A navegação consulta e descarregamento dos títulos inseridos nas Bibliotecas Digitais UC Digitalis, UC Pombalina e UC Impactum, pressupõem a aceitação plena e sem reservas dos Termos e Condições de Uso destas Bibliotecas Digitais, disponíveis em https://digitalis.uc.pt/pt-pt/termos.

Conforme exposto nos referidos Termos e Condições de Uso, o descarregamento de títulos de acesso restrito requer uma licença válida de autorização devendo o utilizador aceder ao(s) documento(s) a partir de um endereço de IP da instituição detentora da supramencionada licença.

Ao utilizador é apenas permitido o descarregamento para uso pessoal, pelo que o emprego do(s) título(s) descarregado(s) para outro fim, designadamente comercial, carece de autorização do respetivo autor ou editor da obra.

Na medida em que todas as obras da UC Digitalis se encontram protegidas pelo Código do Direito de Autor e Direitos Conexos e demais legislação aplicável, toda a cópia, parcial ou total, deste documento, nos casos em que é legalmente admitida, deverá conter ou fazer-se acompanhar por este aviso. 


\section{GROWTH AND \\ MATURATION \\ IN HUMAN BIOLOGY \\ AND SPORTS}

FESTSCHRIFT HONORING ROBERT M. MALINA

BY FELLOWS AND COLLEAGUES

PETER TODD KATZMARZYK MANUEL J COELHO E SILVA

EDITORS 


\title{
NEW DIRECTIONS IN THE STUDY OF MATURATION AND PHYSICAL ACTIVITY
}

\author{
Sean P. Cumming
}

Those interested in the study and promotion of physical activity in children and adolescents have focussed predominantly on the contributions of various psychosocial and environmental factors (Cumming \& Riddoch, 2009). Although it is well documented that factors such as self-concept, motivation, and the built environment contribute to physical activity in youth, it is equally apparent that physical activity has a biological basis (Eisenmann \& Wickel, 2009; Rowland, 1998; Sherar, Cumming, Eisenmann, Baxter-Jones, \& Malina, 2010). As noted by Malina (2008), physical activity is, after all, a biological process that exists within a cultural context in which various meaning and values are ascribed to it. Thus, a true understanding of physical activity likely resides in the interactions of various biological, psychosocial and environmental factors (Malina, 2008).

A biological process that occurs in all children and youth and may contribute to variance in physical activity is maturation (Eisenmann \& Wickel, 2009; Sherar, et al., 2010). Biological maturation denotes progress towards the mature (i.e., adult) state, and can be viewed in terms of tempo and/or timing (Malina, Bouchard, \& Bar-Or, 2004). Whereas tempo implies the rate at which maturation progresses, timing refers to the time at which maturity-related events, such as age at menarche, or peak height velocity occurs. Within a chronological age group, children and adolescents can vary considerably in maturity timing, with certain individuals, or groups, maturing much earlier or later than others. For example, girls generally enter puberty two years in advance of boys.

Research examining the contribution of biological maturation to adolescent involvement in physical activity has produced mixed results (Sherar, et al., 2010). Although research has consistently shown that advanced maturation explains why girls are less active and more sedentary when compared against boys of the same chronological age (Cumming, Standage, Gillison, \& Malina, 2008; Machado Rodrigues et al., 2010 ; Sherar, Esliger, Baxter-Jones, \& Tremblay, 2007; Thompson, Baxter-Jones, Mirwald, \& Bailey, 2003); the effects of maturity timing on individual variation in physical activity within sex are unclear (Sherar, et al., 2010). The physical and functional characteristics associated with advanced maturation in females are considered to be less conducive to successful engagement in most forms of physical activity, particularly activities or sports that involve elements of endurance or weightbearing (Baxter-Jones, Thompson, \& Malina, 2002; Malina, 1994). Accordingly, it has been hypothesized that early maturation in females will be associated with less involvement in most forms of PA (Sherar, et al., 2010). In support of this contention, a number of studies have found early maturing girls to be less active than their 'on time' or late maturing peers (Baker, Birch, Trost, \& Davison, 2007; Cumming et al., in 
press-a; Cumming, et al., 2008; Cumming et al., 20 I I; Davison, Werder, Trost, Baker, \& Birch, 2007; Hunter Smart et al., in press; Jackson, 20II; Riddoch et al., 2007), and less likely to be represented in competitive sports programmes (Baxter-Jones, et al., 2002; Malina, 1994). It should be noted, however, that an equivalent number of studies have no found no relation between maturity timing and PA in adolescent females (Bradley, McRitchie, Houts, Nader, \& O'Brien, 20I I; Drenowatz et al., 20 I0; Knowles, Niven, Fawkner, \& Henretty, 2009; Niven, Fawkner, Knowles, \& Stephenson, 2007; Romon et al., 2004; Sherar et al., 2009; Wickel \& Eisenmann, 2007). That said, only one study, to date, has found early maturing girls to be more active than their peers (van Jaarsveld, Fidler, Simon, \& Wardle, 2007).

The nature and direction of the relation between maturity timing and PA in adolescent males is less clear (Sherar, et al., 20l0). The physical and functional characteristics associated with early maturation in males are considered to be more conducive to successful engagement in most structured or competitive forms of PA, particularly those that emphasise power, speed, and strength (Malina, 1994). Although early maturing male are more likely to be represented in competitive sports programmes (especially in the older age groups and more elite level programmes) (Malina \& Cumming, 2003), there is limited evidence to suggest that early maturing males are actually more or less active than their peers (Sherar, et al., 2010). This suggests that late maturing males, though less likely to be active through competitive sports, remain active in other domains such as recreational play or exercise.

A criticism of research examining relations between biological maturation and physical activity in youth is that it is largely atheoretical, lacking a clear conceptual framework from which to explain and interpret findings (Cumming et al., in press-b; Sherar, et al., 2010). A number of existing conceptual models and hypotheses relating to adolescent and pubertal adjustment, such as Petersen and Taylor's (1980) Model of Biopsychosocial Development, Holmbeck's (2002) Framework for Understanding Adolescent Development and Adjustment, the Peer Socialization Hypothesis (Magnusson, Stattin, \& Allen, 1985, 1986), the Puberty-Initiated Mediation Hypothesis (Ge \& Natsuaki, 2009; Ge, Natsuaki, Jin, \& Biehl, 20II), and the ContextualAmplification Hypothesis (Ge, et al., 20I I; Ge, Brody, Conger, Simons, \& Murry, 2002) suggest possible mechanisms that may help explain relations between maturation and PA during adolescence.

Conceptual models of adolescent development and adjustment can be grouped into two main categories, namely direct and mediated effects (Petersen \& Taylor, 1980). Direct effect models contend that maturation exerts a direct causal effect of adolescent psychology and behaviour. Accordingly, adolescent changes in psychology and behaviour, for example reductions in physical activity, are considered to reflect maturity associated changes in biology (i.e., body size, composition, physique, neuroendocrine changes) and attribute individual differences in behaviour to differences in antecedent variables (i.e., biology). Direct effect models would consider adolescent declines in physical activity as an inescapable consequence of the maturation process and 'invariant and universal' feature of adolescent and/or pubertal development (Petersen \& Taylor, 1980). 


\section{DIRECT EFFECTS}

Support for the existence of direct effects is limited. Though some evidence has linked hormones to changes in mood and behaviour (i.e., aggression, sexual behaviour), it is weaker and less consistent than is commonly believed (Buchanan, Eccles, \& Becker, 1992; Petersen \& Taylor, 1980; Walker, Sabuwalla, \& Huot, 2004). This may, however, reflect methodological limitations (e.g., lack of precision and consistency in measurements of hormones and psycho-behavioural outcomes) rather than inadequacies in the theoretical paradigm (Petersen \& Taylor, 1980). Despite the lack of evidence supporting the hormonal effects of maturation on psychology and behaviour, the potential for direct effects may be greater in the context of physical activity (Cumming, et al., in press-b). One of the most consistent findings in pediatric exercise science is that individuals become less active as they progress towards the mature state (Eisenmann \& Wickel, 2009). The fact that this change is observed across most animal species (Ingram, 2000) also suggests a biological basis for the phenomenon. In support of this contention, research has consistently found that sexrelated differences in physical activity and sedentary behaviour among adolescents of the same chronological age are attenuated and non-significant when differences biological maturation are controlled for (i.e., girls typically mature two years in advance of boys) (Cumming, et al., 2008; Machado Rodrigues, et al., 20 I0; Sherar, et al., 2007; Thompson, et al., 2003).

Further evidence supporting the potential for a direct effect of maturation on physical activity can be found in research examining the purpose of active play (Byers, 1998; Byers \& Walker, 1995; Pellegrini \& Smith, 1998a, 1998b). Active play is a behaviour that occurs frequently in early and late childhood, yet declines in adolescence through to adulthood. It can also be observed in many animal species, tending to peak around midlaction (Byers, 1998; Byers \& Walker, 1995). These observations have led theorists to contend that play is a biologically driven phenomenon that aims to enhance development during time sensitive periods (Byers, 1998. Time sensitive effects that are permanent and specific to play include synaptic pruning, myelination of the neural fibre tracts, and muscle fibre type differentiation (Byers, 1998. Recognizing play as a biological drive, whose purpose is limited to childhood and adolescence, provides a compelling explanation as to why individuals become less active as the progress towards the mature state (Cumming, et al., in press-b). That is, play becomes biologically redundant once certain developmental processes are complete.

\section{INDIRECT EFFECTS}

Mediated effect' models contend that the psychological and behavioural effects of maturation are mediated and/or moderated by factors endogenous or exogenous to the individual, respectively (Petersen \& Taylor, 1980). Mediating factors might include beliefs, self-perceptions, and fantasies and/or attitudes towards the body, physical

' It should be noted that the term 'mediated effects model' is somewhat of a misnomer as such models recognize both mediated and moderate effects 
activity, and/or maturation process(Cumming, et al., in press-b). Factors that might moderate relations between maturation and physical activity include peer acceptance, parental support, motivational climate, and cultural values and standards pertaining to the body, maturation, and/or physical activity (Cumming, et al., in press-b). Unlike direct effect models, mediated effect models attribute individual differences in pubertal adaptation to differences in the interpretation and social management of puberty (Petersen \& Taylor, 1980). That is, how the individual interprets change during puberty and the meaning and value attached to change is considered to be more important than the change itself. Applying these principles to the context of physical activity, one would predict that youth who are encouraged to view puberty as a normal and positive aspect of the maturation process and not as a barrier to activity would be more likely to remain active through adolescence (Cumming, et al., in pressb).

Potential mediators of relations between maturation and physical activity in adolescents include physical self-concept, body image, self-esteem, acceptance and/or self-presentation anxieties, and attitudes and feelings related to the body, physical activity, and/or the maturation process (Cumming, et al., in press-b; Sherar, et al., 2010). Whereas a number of these potential mediators have been documented as correlates of maturation and physical activity, few studies have actually tested the extent to which these factors actual mediate relations between the variables of interest.

A variable that has received particular interest, as a mediator of relations between maturation and PA, is physical self-concept. Physical self-concept represents the individuals perceptions of the self as generated through his or her experiences with, and interpretations of, the environment related to the physical domain (Shavelson, Hubner, \& Stanton, 1976). It has been documented as both a correlate of maturation (Craft, Pfeiffer, \& Pivarnik, 2003; Niven, et al., 2007) and as a predictor and outcome of physical activity (Sabiston \& Crocker, 2008; Weiss \& Amorose, 2005). Advanced maturation in females is generally associated with lower perceptions of physical self-concept (i.e., body attractiveness, sport competence, physical condition, physical self-worth), though early maturing girls do report higher perceptions of strength (Cumming, et al., in press-b). In contrast, advanced maturation in males is typically associated with superior physical self-concept (Lintunen, Rahkila, Silvennoinen, \& Osterback, 1988), though evidence is limited.

To date, only a limited number of studies have examined the degree to which physical self-concept actually mediates relations between maturation and physical activity. In a series of three studies testing a mediated effects model, Cumming and colleagues (Cumming, et al., 20ll; Hunter Smart, et al., in press) tested the mediating effect of physical self-concept upon relations between maturation and physical in adolescent British females. In each study an inverse indirect relation was observed between maturity timing and physical activity. That is, early maturing girls were typically less active than their peers. Similarly, in each study, perceptions of selfcompetence were found to partially mediate relations between maturation and physical activity. More specifically, girls who were advanced in their maturation generally held lower perception of body attractiveness, sport competence, physical 
conditioning, and physical self-worth (yet greater strength), which, in turn, predicted less involvement in physical activity.

As noted previously, the effects of maturation on behaviours such as PA may be moderated by social or cultural factors. The Peer Socialization hypothesis, advanced by Magnusson and colleagues (Magnusson, et al., 1985, 1986), contends that adolescents select peers who are similar in maturity status and, as a consequence, behave in manner that is consistent with their peer groups. Though there is emerging evidence to suggest that early maturing females are less active than their on-time or late maturing peers (Sherar, et al., 20l0), it is not clear whether or not this is a result of their associations with older and less active peers. Accordingly, future studies should consider applying the Peer Socialization Hypothesis within the context of physical activity.

Similar to the peer socialization hypothesis, the Puberty-initiated Mediation Hypothesis (Ge \& Natsuaki, 2009; Ge, et al., 20II) suggests that the physical and functional characteristics associated with variance in maturity timing hold social stimulus value for significant others (i.e., peers, parents, educators) influencing their perceptions of the adolescent and the nature and quality of their social interactions. Applied to the context of physical activity, the physical and functional characteristics associated with average-to-late maturation in females and average-to-early maturation in males would be considered to be more suitable for successful engagement in most forms of physical activity, especially sports (Malina, 1994). Accordingly, one would expect those individuals to experience a more positive and supportive environment within the context of physical activity (Cumming, et al., in press-b). In support of this contention, Summers-Efler (2004) found that social support from peers and parents, or lack thereof, play an instrumental role in helping adolescent females remain active through puberty. In a similar vein, Cumming and colleagues found that body size in gymnastics was closely related to girls perceptions of coaching behaviours, with girls who were shorter, light, and who carried less mass-for-stature reporting more frequent reinforcement and encouragement, instruction, general communication, and less punishment or ignoring behaviours (Cumming, Eisenmann, Smoll, Smith, \& Malina, 2005).

The Contextual Amplification Hypothesis (Ge, et al., 201 I; Ge, et al., 2002) has also been proposed to explain the impact of social and cultural factors upon adolescent adjustment. Much like the Peer Socialization and Puberty-initiated Mediation hypotheses, this hypothesis assumes that the sociocultural context in which the adolescent grows up plays an important role in moderating relations between maturity timing and problem behaviours, such as inactivity. Whereas protective or supportive contexts are expected to mitigate any negative consequences associated with variation in maturation (i.e. reduced activity, increased sedentary behaviour), adverse conditions would be expected to amplify these effects. For example, an early maturing adolescent female experiencing an environment that supports activity would be expected to remain as active as her average and late maturing peers. In contrast, an early maturing girl who received limited parental or peer support, grew up in a disadvantaged neighbourhood, or lived in a culture that frowned upon public exercise in females would be less likely to remain active. 
To date, only a limited number of studies have explicitly investigated the potential for social and cultural factors to moderate relations between maturation and physical activity. Assuming that a more supportive social environment would mitigate any negative effects associated with advanced maturation on physical activity in females, Pindus and colleagues examined the extent to which peers acceptance moderated relations between maturity timing and physical activity in British adolescent females (Pindus et al., 20ll). As expected, advanced maturation was found to be associated with less involvement in physical activity. However, early maturing girls who perceived high levels of peer acceptance were found to be as active as their 'on time' or 'late' maturing peers. In a related study, the moderating effect of parental support for physical activity on relations between maturity timing and physical activity in British adolescent females, aged II to 14 years was also studied (Jackson, 20 I I). Although advanced maturation was associated with less involvement in physical activity, a statistically significant moderating effect for parental support was not observed. Nevertheless, early maturing girls who reported higher levels of parental support reported, on average, higher levels of physical activity than those who reported lower levels of parents support.

Assuming that parental support might mitigate any negative impact of advanced maturation on physical activity in adolescents, Bradley and colleagues examined the relation between maturity timing and parental support on adolescent involvement in moderate-to-vigorous physical activity (MVPA) (Bradley, et al., 20l I). Although pubertal timing was found to be unrelated to MVPA in both males and females, parental support moderated the effect of pubertal timing on MVPA in males. Closer inspection of the results suggested that higher levels of high parental monitoring was associated with reduced physical activity in late maturing males, but increased activity levels for early maturing males. The finding of this study should, however, be interpreted with caution as the growth models used to predict change in MVPA included exceptionally large numbers of independent and interactive predictor variables.

\section{SUMMARY}

Emerging evidence suggests that biological maturation and pubertal timing both contribute to variance in physical activity in adolescents. What is also clear is that the relations between biological maturation and physical activity are complex and that a variety of personal and social cultural factors may mediate or moderate relations between these constructs. Professor Malina has undoubtedly played a major role in leading and advancing this line of research, identifying the need to adopt a biocultural approach to the study of maturation and activity and encouraging fellow researchers in their efforts to study this phenomenon. In this respect, I and many of my colleagues will be eternally grateful for his contribution to the field of study, and for his continued advice, support and friendship. 


\section{REFERENCES}

Baker, B.L., Birch, L.L., Trost, S.G. and Davison, K.K., 2007, Advanced pubertal status at age II and lower physical activity in adolescent girls. Journal of Pediatrics, | 5 | (5), pp. 488-493.

Baxter-Jones, A.D.G., Thompson, A.M. and Malina, R.M., 2002, Growth and maturation in elite young female athletes. Sports Medicine and Arthroscopy Review, I O ( I), pp. $42-49$.

Bradley, R.H., McRitchie, S., Houts, R.M., Nader, P. and O'Brien, M., 20II, Parenting and the decline of physical activity from age 9 to 15. International Journal of Behavioral Nutrition and Physical Activity, 8(33), doi: I0.1 186/1479-5868-8-33.

Buchanan, C.M., Eccles, J.S. and Becker, J.B., 1992, Are adolescents the victims of raging hormones - Evidence for activational effects of hormones on moods and behavior at adolescence. Psychological Bulletin, I I I ( I), pp. 62-107.

Byers, J.A., 1998, The biology of human play. Child Development, 69 (3), pp. 599-600.

Byers, J.A. and Walker, C., 1995, Refining the motor training hypothesis for the evolution of play. American Naturalist, I 46( I), pp. 25-40.

Craft, L.L., Pfeiffer, K.A. and Pivarnik, J.M., 2003, Predictors of physical competence in adolescent girls. Journal of Youth and Adolescence, 32(6), pp. 43I-438.

Cumming, S.P., Eisenmann, J.C., Smoll, F.L., Smith, R.E. and Malina, R.M., 2005, Body size and perceptions of coaching behaviors by adolescent female athletes. Psychology of Sport and Exercise, 6(6), pp. 693-705.

Cumming, S.P. and Riddoch, C., 2009, Physical activity, physical fitness, and health: Current concepts. In Paediatric Exercise Science and Medicine, edited byArmstrong, N. and Van Mechelen, W., (Oxford University Press), pp. 327338.

Cumming, S.P., Sherar, L.B., Hunter Smart, J.E., Machado Rodrigues, A.M., Standage, M., Gillison, F.B. and Malina, R.M., in press-a, Differences in the physical activity, physical self-concept, and health-related quality of life between adolescent females at the extremes of the biological maturity continuum. Journal of Early Adolescence.

Cumming, S.P., Sherar, L.B., Pindus, D.M., Coelho e Silva, M.J., Malina, R.M. and Jardine, P.R., in press-b, A biocultural model of maturity associated variance in adolscent physical activity. International Review of Sport and Exercise Psychology.

Cumming, S.P., Standage, M., Gillison, F. and Malina, R.M., 2008, Sex differences in exercise behavior during adolescence: is biological maturation a confounding factor? Journal of Adolescent Health, 42(5), pp. 480-485.

Cumming, S.P., Standage, M., Loney, T., Gammon, C., Neville, H., Sherar, L.B. and Malina, R.M., 20II, The mediation effect of physical self-concept on relations between biological maturity status and physical activity in adolescent females. Journal of Adolescence, 34, pp. 465-473.

Davison, K.K., Werder, J.L., Trost, S.G., Baker, B.L. and Birch, L.L., 2007, Why are early maturing girls less active? Links between pubertal development, psychological well-being, and physical activity among girls at ages II and I3. Social Science \& Medicine, 64, pp. 2391-2404.

Drenowatz, C., Eisenmann, J.C., Pfeiffer, K.A., Wickel, E.E., Gentile, D. and Walsh, D., 2010, Maturity-related differences in physical activity among 10-to 12-year- 
old girls. American Journal of Human Biology, 22(1), pp. 18-22. doi: 10.1002/ajhb.20905

Eisenmann, J.C. and Wickel, E.E., 2009, Biology of physical activity in children: Revisited. Pediatric Exercise Science, 2 I (3), pp. 257-272.

Ge, X. and Natsuaki, M., 2009, In search of explanations for early pubertal timing effects on developmental psychopathology. Current Directions in Psychological Science, I 8, pp. 327-331.

Ge, X., Natsuaki, M.N., Jin, R. and Biehl, M., 20ll, A contextual amplification hypothesis. Pubertal timing and girls' problem behaviors. In , Understanding Girls' Problem Behavior: How Girls' Delinquency Develops in the Context of Maturity and Health, Co-occuring Problems and Relationships, edited by Kerr, M., Stattin, H., Engels, R.C.M.E., Overbeek, G. and A. K. Andershed, A.K., (London: Wiley), pp. II-29.

Ge, X.J., Brody, G.H., Conger, R.D., Simons, R.L. and Murry, V.M., 2002, Contextual amplification of pubertal transition effects on deviant peer affiliation and externalizing behavior among African American children. Developmental Psychology, 38(I), pp. 42-54. doi: Doi 10.1037//00 I2-1649.38.1.42

Holmbeck, G.N., 2002, A developmental perspective on adolescent health and illness: An introduction to the special issues. Journal of Pediatric Psychology, 27(5), pp. 409-416.

Hunter Smart, J.E., Cumming, S.P., Sherar, L.B., Standage, M., Neville, H. and Malina, R.M., in press, Maturity associated variance in physical activity and healthrelated quality of life in adolescent females. A mediated effects model. Journal of Physical Activity \& Health.

Ingram, D.K., 2000, Age-related decline in physical activity: generalization to nonhumans. Medicine and Science in Sports and Exercise, 32(9), pp. 16231629.

Jackson, L., 201I, The Moderating Effect of Parental Support on Physical Activity and Physical Self-concept in Early, On Time, and Late Maturing Girls. Undergraduate Honours Degree in Sport and Exercise Science, University of Bath, Bath.

Knowles, A., Niven, A.G., Fawkner, S.G. and Henretty, J.M., 2009, A longitudinal examination of the influence of maturation on physical selfperceptions and the relationship with physical activity in early adolescent girls. Journal of Adolescence, 32(3), pp. 555-566.

Lintunen, T., Rahkila, P., Silvennoinen, M. and Osterback, L., 1988, Psychological and physical correlates of early and late biological maturation in 9- to I I-year-old girls and boys. In Young Athletes: Biological, Psychological, and Educational Perspectives, Edited by Malina, R.M., (Champaign, Ill: Human Kinetics).

Machado Rodrigues, A.M.M., Coelho-e-Silva, M.J., Mota, J., Cumming, S.P., Sherar, L.B., Neville, H. and Malina, R.M., 2010, Confounding effect of biologic maturation on sex sifferences in physical activity and sedentary behavior in adolescents. Pediatric Exercise Science, 22(3), pp. 442-453.

Magnusson, D., Stattin, H. and Allen, V.L., 1985, Biological maturation and socialdevelopment - a longitudinal-study of some adjustment processes from midadolescence to adulthood. Journal of Youth and Adolescence, I 4(4), pp. 267283. 
Magnusson, D., Stattin, H. and Allen, V.L., 1986, Differential maturation among girls and its relations to social-adjustment - a longitudinal perspective. Life-Span Development and Behavior, 7, pp. 135- 173.

Malina, R.M., 1994, Physical growth and biological maturation of young athletes. Exercise and Sport Sciences Reviews, 22, pp. 389-433.

Malina, R.M., 2008, Biocultural factors in developing physical activity levels. In Youth Physical Activity and Inactivity, edited by Smith, A.L. and Biddle, S.J.H.,(Champaign, III.: Human Kinetics),pp. |4|- 166.

Malina, R.M. Bouchard, C. and Bar-Or, O., 2004, Growth Maturation and Physical Activity, (Champaign, IL: Human Kinetics).

Malina, R.M. and Cumming, S.P., 2003, Current status and issues in youth sports. In Youth Sports: Perspectives for a New Century, edited by Malina, R.M. and M. A. Clark, M.A., (Monterey, CA: Coaches Choice).

Niven, A.G., Fawkner, S.G., Knowles, A. and Stephenson, C., 2007, Maturational differences in physical self-perceptions and the relationship with physical activity in early adolescent girls. Pediatric Exercise Science, 19, pp. 472-480.

Pellegrini, A.D. and Smith, P.K., 1998a, Physical activity play: Consensus and debate. Child Development, 69(3), pp. 609-6I0.

Pellegrini, A.D. and Smith, P.K., 1998b, Physical activity play: The nature and function of a neglected aspect of play. Child Development, 69(3), pp. 577-598.

Petersen, A.C. and Taylor, B., 1980, The biological approach to adolescence: Biological change and psychological adaptation. In Handbook of Adolescent Psychology, edited byAdelson, J., (New York: Wiley-Interscience), pp. I 17-I55.

Pindus, D.M., Cumming, S.P., Sherar, L.B., Gammon, C., Coelho-e-Silva, M.J. and Malina, R.M., 20II, Maturity-associated Variation in Physical Activity and Health-related Quality of Life: Moderating Effects of Peer Acceptance. Department for Health. University of Bath. Bath.

Riddoch, C., Mattocks, C., Deere, K., Saunders, J., Kirkby, J., Tilling, K., ... and Ness, A., 2007, Objective measurement of levels and patterns of physical activity. Archives of Disease in Childhood, 92, pp. 963-969.

Romon, M., Lafay, L., Bresson, J.L., Oppert, J.M., Borys, J.M., Kettaneh, A. and Charles, M.A., 2004, Relationships between physical activity and plasma leptin levels in healthy children: the Fleurbaix-Laventie Ville Sante II Study. International Journal of Obesity, 28(I0), pp. I227-1232. doi: DOI 10.1038/sj.ijo.0802725

Rowland, T.W., 1998, The biological basis of physical activity. Medicine and Science in Sports and Exercise, 30(3), pp.392-399.

Sabiston, C.M. and Crocker, P.R.E., 2008, Exploring self-perceptions and social influences as correlates of adolescent leisure-time physical activity. Journal of Sport \& Exercise Psychology, 30( I), pp. 3-22.

Shavelson, R.J., Hubner, J.J. and Stanton, G.C., 1976, Self-concept: Validation of construct interpretations. Review of Educational Research, 46, pp. 407-4II.

Sherar, L.B., Cumming, S.P., Eisenmann, J.C., Baxter-Jones, A.D.G. and Malina, R.M., 2010, Adolescent biological maturity and physical activity: Biology meets behaviour, Pediatric Exercise Science, 22(3), pp. 332-349.

Sherar, L.B., Esliger, D.W., Baxter-Jones, A.D.G. and Tremblay, M.S., 2007, Age and gender differences in youth physical activity: Does physical maturity matter? Medicine and Science in Sports and Exercise, 39(5), pp. 830-835. 
Sherar, L.B., Gyurcsik, N.C., Humbert, M.L., Dyck, R.F., Fowler-Kerry, S. and BaxterJones, A.D.G., 2009, Activity and barriers in girls (8-16 yr) based on grade and maturity status, Medicine and Science in Sports and Exercise, 4I (I), pp. 87-95.

Summers-Efler, E., 2004, Little girls in women's bodies: Social interaction and the strategizing of early breast development. Sex Roles, 5 I , pp. 29-44.

Thompson, A.M., Baxter-Jones, A.D.G., Mirwald, R.L. and Bailey, D.A., 2003, Comparison of physical activity in male and female children: Does maturation matter? Medicine and Science in Sports and Exercise, 35(10), pp. I684- 1690.

van Jaarsveld, C.H.M., Fidler, J.A., Simon, A.E. and Wardle, J., 2007, Persistent impact of pubertal timing on trends in smoking, food choice, activity, and stress in adolescence. Psychosomatic Medicine, 69(8), pp. 798-806.

Walker, E.F., Sabuwalla, Z. and Huot, R., 2004, Pubertal neuromaturation, stress sensitivity, and psychopathology. Development and Psychopathology, I 6(4), pp. 807-824. doi: Doi I 0.1017/S0954579404040027

Weiss, M.R. and Amorose, A.J., 2005, Children's self-perceptions in the physical domain: Between- and within-age variability in level, accuracy, and sources of perceived competence. Journal of Sport \& Exercise Psychology, 27(2), pp. 226244.

Wickel, E.E. and Eisenmann, J.C., 2007, Maturity-related differences in physical activity among 13-14- year old adolescents. Pediatric Exercise Science, 19(4), pp. 384392. 